Research Article

OOpen Access

D) CrossMark

\title{
Refugees' coping strategies towards stressful life events
}

\section{Summary}

In the present research-, that took place in 'Praksis' offices, counseling centres of the N.G.O. 'Doctors without frontiers' in Athens, Greece-99 Refugees were participated: 62 males and 36 females. Their countries of origin were: Syria, Ivory Coast, Afghanistan, Zaire, Eritrea, Iraqi, Iran, Cameroon, Mauritania, Miramar, Nigeria, Palestine, Sierra Leone, Senegal, Somalia, Sudan, Sri Lanka, and Turkey.

The purpose of the study was to investigate which coping strategies were used by the refugees, who lived in traumatic life situations. It was found out that a variety of coping strategies were selected, so that those refugees could surpass their painful experiences andadjust gradually in their new way of life, away from their home country. Specifically, strategies mostly used were social support (65\%), behavioral change (55\%), faith in God $(80 \%)$ and the effort to control negative emotions $(40 \%)$.
Volume 4 Issue 4 - 2015

Theodoratou Maria, ' Valsami M, ${ }^{2}$ Dritsas J, ${ }^{2}$

Bekos $\mathrm{V}^{2}$

'Department of Social Work, T.E.I. of Western Greece

${ }^{2}$ Karamandaneion Pediatric Hospital, Patras, Greece

Correspondence: Maria Theodoratou, Clinical Psychologist, Technological Institute of Patras, School of Health and Welfare Professions, Patras, Greece, Email mttheoria3@gmail.com

Received: October 27, 2015 | Published: December 16, 2015

\section{Background}

It is well known that many refugees have experienced various forms of violence, including death of family members, physical violence, sexual assaults, shelling and other forms of torture. ${ }^{1}$

Coping is "constantly changing cognitive and behavioral efforts to manage specific external and/ or internal demands that are appraised as taxing or exceeding the resources of the person". This became the most widely accepted and used definition during the 1980's. ${ }^{2}$

In order to cope with their life in transit and exile, refugees have to learn not only how to reduce the stress which results from disruption programmes set up to help them (Knudsen,1991). Refugees' coping strategies are investigated, given that being a refugee may be related to depression by focusing on personal coping responses. However, in their way of life, but also how to come to terms with relief

strategies such as acculturation and ethnic social support, moderate the impact of negative experiences on mental health and adjustment. ${ }^{3}$

\section{Materials and methods}

During the research process 99 Refugees were participated: 62 males and 32 females. Their countries of origin were: Ivory Coast, Afghanistan, Zaire, Eritrea, Iraqi, Iran, Cameroon, Mauritania, Miramar, Nigeria, Palestine, Sierra Leone, Senegal, Somalia, Sudan, Sri Lanka, Syria and Turkey.

The respondents were not asked about their family situation, neither their academic standards. The only obligation to the research, they had to be over 18years old. The coping strategy scale of "Echelle Toulousaine de Coping"4 as research tool was used and was consisted of 54 questions. All participants were interviewed by the agency social worker and one of the researchers. The aim of the study was to explore how the Refugees chose coping strategies (Figure 1).

\begin{tabular}{|c|c|c|c|}
\hline & \multicolumn{3}{|l|}{ Coping Strategies' } \\
\hline & \multicolumn{3}{|l|}{ ASPECTS } \\
\hline & Action & Information Seeking & Emotion \\
\hline Focus & Active Focus & Cognitive Focus & Emotional Focus \\
\hline Social Support & \multirow{3}{*}{$\begin{array}{l}\text { Cooperation } \\
\text { Social and Behavioural } \\
\text { Withdrawal } \\
\text { Attitude Change }\end{array}$} & \multirow{3}{*}{$\begin{array}{l}\text { Informational social support } \\
\text { Mental } \\
\text { Withdrawal } \\
\text { Acceptance }\end{array}$} & Emotional social support \\
\hline Withdrawl & & & Addiction \\
\hline Attitude Change & & & Values Change \\
\hline Control & Activities' Regulation & Cognitive control and planning & Emotional Control \\
\hline Denial & Entertainment & Denial & Alexithymia \\
\hline
\end{tabular}

Figure I Coping Strategies'. ${ }^{4}$

\section{Results}

The research findings revealed that the Refugees who visited Praxis Health Centres used a wide range of coping strategies. In particular, strategies mostly used were social support (65\%), behavioral change $(55 \%)$, faith in God (80\%) and the effort to control negative emotions (40\%) (Figure 2).

As a coping strategy frequently reiterated by participants, it provided meaning to life circumstances, helped develop self- confidence, and played a key role in how participants coped with adversity. As a matter of fact, emotional support was frequently derived through prayer and religious belief, fact that many similar researches underline ${ }^{5}$ (Figure 3).

Greater numbers of peers and family members in Greece, and a higher reliance on religious support mechanisms decreased the likelihood of major depression, fact that is highligtened by researches on Immigrants in other countries. ${ }^{6,7}$ 


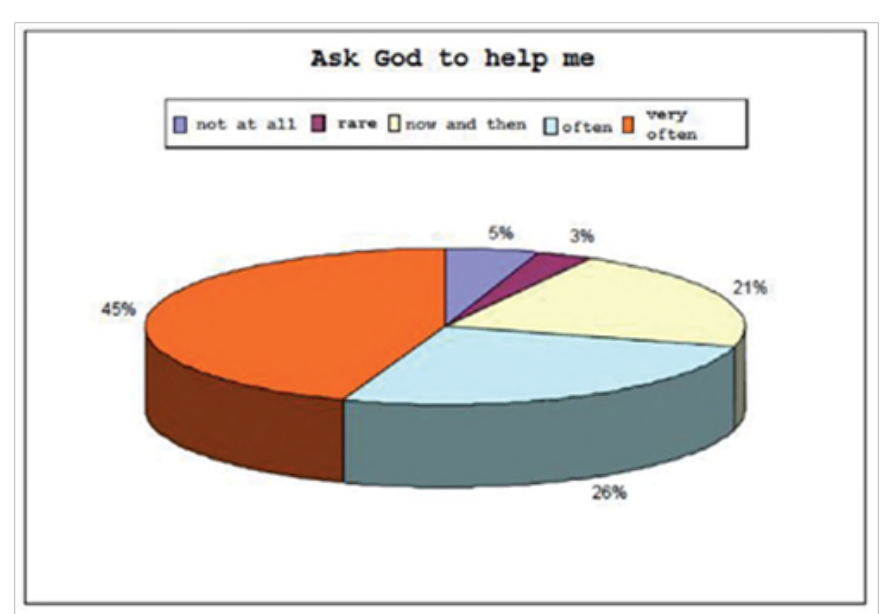

Figure 2 Asking God's help.

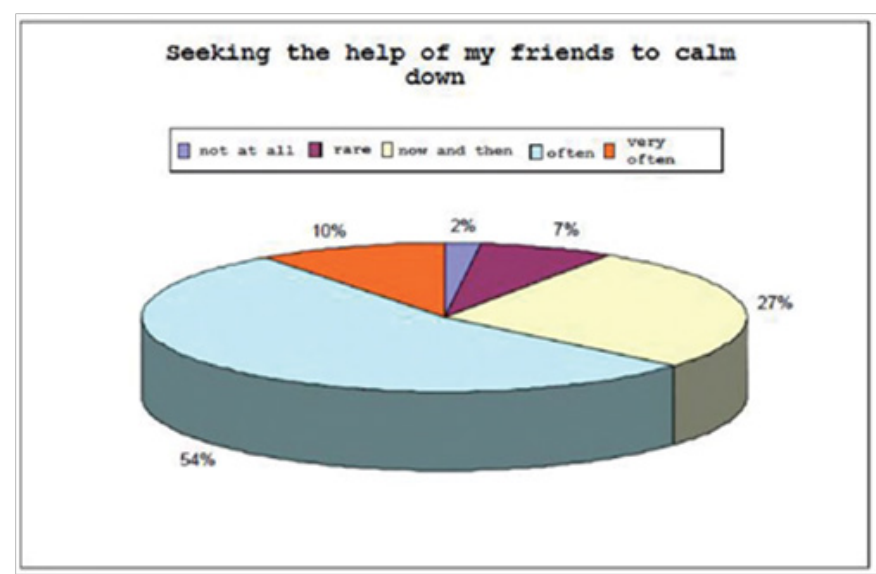

Figure 3 Emotional social support.

\section{Conclusion}

Refugees coping strategies are mainly social support and faith to God. However, projects are needed to promote the management of migration. Trainings should inform people about more effective coping strategies, such as instrumental support and respect of refugees' human rights. Last, but not least, programs empowering refugees could help them to integrate into the host country successfully.

\section{Acknowledgements}

Many thanks to 'Praxis' of N.G.O. 'Doctors without frontiers'.

\section{Conflicts of interest}

Author declares there are no conflicts of interest.

\section{Funding}

None.

\section{References}

1. Neuner F, Schauer M, Karunakara U, et al. Psychological trauma and evidence for enhanced vulnerability for posttraumatic stress disorder through previous trauma among West Nile refugees. BMC psychiatry. 2004;4(1):34

2. Farwell N. In war's wake: Contextualizing trauma experiences and psychosocial well- being among Eritrean youth. International Journal of Mental Health. 2004;32(4):20-50.

3. Noh S, Kaspar V. Perceived Discrimination and Depression: Moderating Effects of Coping, Acculturation, and Ethnic Support. Am J Public Health. 2003;93(2):232-238.

4. Sordes F, Esparbès Tap P. Présentation de l'Echelle Toulousaine de Coping. Journées de Labo St Criq. 1993.

5. Thomas FC, Roberts B, Luitel NP, et al. Resilience of refugees displaced in the developing world: a qualitative analysis of strengths and struggles of urban refugees in Nepal. Confl Health. 2011;5(1):20.

6. Finch BK, Vega WA. Acculturation Stress, Social Support, and Self-Rated Health Among Latinos in California. J Immigr Health. 2003;5(3):109-117.

7. Schweitzer R, Melville F, Steel Z, et al. Trauma, Post-Migration Living Difficulties, and Social Support as Predictors of Psychological Adjustment in Resettled Sudanese Refugees. Aust N Z J Psychiatry . 2006;40(2):179-187. 